\author{
Agnieszka WIATER ${ }^{1}$ \\ Mateusz RAJCHEL ${ }^{2}$ \\ Tomasz SIWOWSKI ${ }^{3}$
}

\title{
BADANIA PLYT POMOSTU Z BETONU LEKKIEGO ZBROJONYCH PRĘTAMI KOMPOZYTOWYMI GFRP
}

\begin{abstract}
Płyty betonowe w obiektach mostowych maja najmniejsza trwałość spośród wszystkich ich elementów. Jednym ze sposobów zwiększenia ich trwałości jest zastosowanie do ich zbrojenia są prętów kompozytowych, które charakteryzują się wysoką odpornością na korozję, a także wysoką wytrzymałością i małym ciężarem własnym. Badania prowadzone od kilku lat w Kanadzie, USA oraz Japonii zarówno w warunkach laboratoryjnych jak również w rzeczywistych warunkach eksploatacji mostów wykazały, że betonowe płyty pomostu zbrojone prętami kompozytowymi zachowują się bardzo dobrze pod obciążeniem i mają zdecydowanie większą trwałość. Celem pracy jest przedstawienie własnych badań statycznych i zmęczeniowych betonowych płyt pomostu zbrojonych prętami kompozytowymi, sprawdzenie ich nośności oraz trwałości zmęczeniowej. W celu uzyskania korzystnej redukcji ciężaru własnego płyt zastosowano konstrukcyjny beton lekki. Uzyskane wyniki porównano z obliczeniami normowymi. Wykazano, że płyty pomostowe $\mathrm{z}$ betonu lekkiego, zbrojone prętami kompozytowymi są pełnowartościową alternatywą dla konwencjonalnych płyt pomostowych.
\end{abstract}

Słowa kluczowe: płyta pomostu, pręty kompozytowe, beton lekki, badania wytrzymałościowe, badania zmęczeniowe

\section{Wprowadzenie}

Korozja stalowych prętów zbrojeniowych jest istotnym czynnikiem ograniczający długość życia konstrukcji betonowych, w szczególności mostów. W drogowych obiektach mostach zjawisko korozji prętów zbrojeniowych jest

\footnotetext{
${ }^{1}$ Autor do korespondencji: Agnieszka Wiater, Politechnika Rzeszowska, Zakład Dróg i Mostów, ul. Poznańska 2, 35-049 Rzeszów, tel. (17) 8651 596, wiater@prz.edu.pl

2 Mateusz Rajchel, Politechnika Rzeszowska, Zakład Dróg i Mostów, ul. Poznańska 2, 35-049 Rzeszów, tel. (17) 8651 596, mrajchel@,prz.edu.pl.

3 Tomasz Siwowski, Politechnika Rzeszowska, Zakład Dróg i Mostów, ul. Poznańska 2, 35-049 Rzeszów, tel. (17) 8651 596, siwowski@.prz.edu.pl.
} 
szczególnie nasilone przez działanie soli stosowanej do odladzania nawierzchni mostowych [21]. Rozległa korozja stali zbrojeniowej powoduje pękanie oraz ubytki w betonowych płytach pomostowych, co prowadzi do kosztownych remontów, powodujących poważne zakłócenia w ruchu drogowym [4]. Jednym ze sposobów rozwiązania tego problemu jest stosowanie prętów zbrojeniowych z materiałów niemetalicznych [[4], [9], [21]]. Niemetaliczne zbrojenie w postaci prętów kompozytowych GFRP (ang. glass fiber reinforded polymers) w betonowych płytach pomostowych może znacznie wydłużyć trwałość, zmniejszyć koszty utrzymania i poprawić efektywność kosztów w cyklu życia obiektu mostowego. Ponadto użycie prętów zbrojeniowych GFRP może również zmniejszyć koszt budowy obiektu, eliminując potrzebę stosowania izolacji mostowych na płycie pomostu [4]. Pręty kompozytowe GFRP stanowią alternatywę dla tradycyjnych prętów zbrojeniowych, które zostały z powodzeniem zastosowane w Kanadzie, USA oraz Japonii w kilku obiektach mostowych [[4], [9], [11], [14], [21], [22]].

Innym zagadnieniem, które jest również przedmiotem licznych badań jest wdrożenie do budownictwa mostowego wysokowartościowych betonów lekkich HPLC [10]. Ich zastosowanie pozwala na blisko 30\% redukcję ciężaru własnego, co ma bardzo duże znaczenie np. w przypadku modernizacji istniejących mostów. Dotychczas główną barierą w szerszym stosowaniu betonu lekkiego w płytach pomostowych była jego stosunkowo wysoka nasiąkliwość, co w przypadku zbrojenia stalowego zwiększało prawdopodobieństwo jego korozji i w konsekwencji destrukcji pomostu. Jednakże połączenie wysokowartościowego betonu lekkiego i prętów kompozytowych wyklucza to zagrożenie, oferując synergię zalet obu materiałów, prowadzącą do lżejszych, trwałych i tańszych w utrzymaniu mostów.

Od kilkunastu lat prowadzone są badania płyt $\mathrm{z}$ betonu zwykłego zbrojonego prętami kompozytowymi. Ich wyniki wykazują wysokość trwałość i bardzo dobre parametry eksploatacyjne płyt betonowych zbrojonych prętami kompozytowymi [4], [5], [8], [10]. Jednym z częściej badanych problemów jest nośność płyt na ścinanie [1] [24]. Niewiele jest jednak prac dotyczących badań płyt pomostu z betonu lekkiego zbrojonego prętami kompozytowymi. Badania nośności na ścinanie paneli pomostowych wykonanych z betonu lekkiego zbrojonego prętami GFRP opisano w pracach [12],[15]. Wyniki porównano z danymi, uzyskanymi dla analogicznych paneli z betonu zwykłego. Wykazano, że panele $\mathrm{z}$ betonu lekkiego zachowują się podobnie pod obciążeniem, lecz mają mniejszą sztywność i nośność na ścinanie w odniesieniu do paneli $\mathrm{z}$ betonu zwykłego.

$\mathrm{W}$ pracy [3] opisano badania płyt $\mathrm{z}$ betonu lekkiego zbrojonego prętami BFRP (pręty z włókien bazaltowych) w układzie swobodnie podpartym i ciągłym, których celem była ocena zgodności parametrów opisujących zachowanie się płyt pod obciążeniem z wielkościami obliczonymi według wytycznych [2]. Wykazano dość duże rozbieżności wskazując konieczność kontynuacji badań 
w szczególności w zakresie nośności na ścinanie. Badania potwierdzające wysoką trwałość zmęczeniową betonowych płyt pomostu zbrojonych prętami GFRP opisano w pracach [6], [7], [25]. Dotyczyły one płyt z betonu zwykłego.

$\mathrm{W}$ pracy przedstawiono badania statyczne i zmęczeniowe, których przedmiotem była płyta pomostu z konstrukcyjnego betonu lekkiego klasy LC 35/38 zbrojona gładkimi prętami kompozytowymi GFRP o średnicy $12 \mathrm{~mm}$. Celem badań było określenie nośności i trwałości zmęczeniowej płyt oraz porównanie wyników badań $\mathrm{z}$ wynikami obliczeń, przeprowadzanych zgodnie $\mathrm{z}$ wytycznymi ACI 440.1R-06 [2]. Procedura obliczeniowa tej normy została poddana szerszej analizie w pracy [23]. Podczas badań modeli płyt pomostu pod obciążeniem statycznym mierzono wartości przemieszczeń pionowych, odkształceń betonu, oceniano morfologię i szerokości rozwartości rys. Wyznaczono maksymalne wartości obciążenia (tzw. nośności graniczne) oraz opisano towarzyszące im postacie zniszczenia. Badania zmęczeniowe pozwoliły na oszacowanie trwałości zmęczeniowej płyt. W wyniku przeprowadzonych badań wykazano, że płyty pomostowe $\mathrm{z}$ betonu lekkiego, zbrojone prętami kompozytowymi mogą być pełnowartościową alternatywą dla konwencjonalnych płyt pomostowych.

\section{Modele badawcze płyt pomostowych}

Badania przeprowadzono na trzech pełnowymiarowych modelach płyt pomostowych o wymiarach 1,90 × 5,14 m i grubości 0,18 m (M1, M2, M3). Modele badawcze zostały wykonane z betonu lekkiego klasy LC 35/38 o gęstości $1970 \mathrm{~kg} / \mathrm{m}^{3}$, zbrojonego dwiema siatkami prętów kompozytowych GFRP o średnicy $12 \mathrm{~mm}$ w rozstawie $8 \mathrm{~cm}$ (rys. 1). Pręty kompozytowe były produktem firmy Mostostal Warszawa S.A. i zostały wytworzone w procesie pultruzji. W celu zwiększenia ich przyczepności do betonu producent zastosował posypkę piaskiem kwarcowym 0,4/0,8. Otulina zbrojenia dolnego i górnego wynosiła $30 \mathrm{~mm}$.

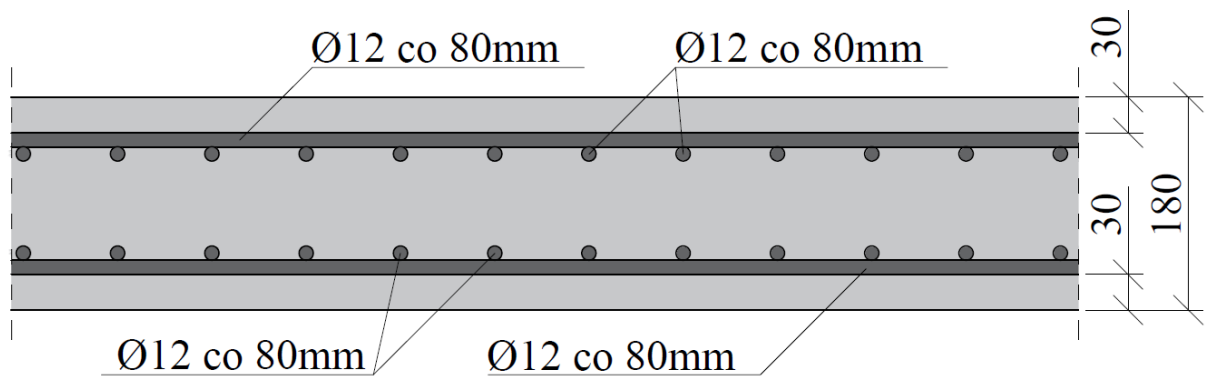

Rys. 1. Schemat zbrojenia płyt pomostu (przekrój poprzeczny)

Fig. 1. The scheme of slabs reinforcement (transverse section) 
W celu ustalenia właściwości mechanicznych prętów kompozytowych GFRP, zostały przeprowadzone badania na rozciąganie pięciu próbek. Wyniki przeprowadzonych prób rozciągania przedstawiono w tabeli 1 . Na podstawie wyników badań określono parametry wytrzymałościowe zbrojenia kompozytowego zgodnie z wytycznymi [2]: wytrzymałość prętów na rozciąganie oraz graniczne odkształcenia jako wartość średnia wyników badań pomniejszone o trzykrotną wartość odchylenia standardowego wyników, natomiast moduł sprężystości jako wartość średnia wyników badań. Uzyskane w ten sposób podstawowe właściwości mechaniczne zastosowanych prętów kompozytowych wyniosły:

- gwarantowana wytrzymałość na rozciąganie: 809,1 MPa;

- moduł Younga: 57,8 GPa,

- odkształcenie graniczne: $1,35 \%$.

Tabela 1. Wyniki badań prętów GFRP na rozciąganie

Table 1. Tensile test results on GFRP bars

\begin{tabular}{|c|c|c|c|c|}
\hline $\begin{array}{c}\text { Symbol } \\
\text { próbki }\end{array}$ & $\begin{array}{c}\text { Sila } \\
\text { niszcząca } \\
{[\mathbf{k N}]}\end{array}$ & $\begin{array}{c}\text { Wytrzymałość } \\
\text { próbek } \\
\text { na rozciaganie } \\
\text { [MPa] }\end{array}$ & $\begin{array}{c}\text { Modul } \\
\text { Younga } \\
\text { [GPa] }\end{array}$ & $\begin{array}{c}\text { Wydłużenie } \\
\text { przy } \\
\text { zerwaniu } \\
{[\%]}\end{array}$ \\
\hline P1 & 114,95 & 995 & 55,6 & 1,68 \\
\hline P2 & 105,87 & 923 & 57,0 & 1,82 \\
\hline P3 & 120,70 & 1038 & 55,7 & 2,19 \\
\hline P4 & 117,17 & 1022 & 58,9 & 1,94 \\
\hline P5 & 121,63 & 1116 & 62,0 & 1,98 \\
\hline $\begin{array}{c}\text { Wartość śred- } \\
\text { nia }\end{array}$ & 116,06 & 1018,8 & 57,8 & 1,92 \\
\hline $\begin{array}{c}\text { Odchylenie } \\
\text { standardowe }\end{array}$ & 6,30 & 69,9 & 2,7 & 0,19 \\
\hline
\end{tabular}

Eksperymentalnie ustalono również wytrzymałość betonu lekkiego na ściskanie. Do tego celu z modelu badawczego M3 po przeprowadzeniu badań wytrzymałościowych pobrano cztery odwierty rdzeniowe o średnicy $100 \mathrm{~mm}$ i wysokości $180 \mathrm{~mm}$ (rys. 2). Zgodnie z normą [17] badanie próbek o nominalnej średnicy nie mniejszej niż $100 \mathrm{~mm}$ i nie większej niż $150 \mathrm{~mm}$ oraz wysokości równej dwukrotnej średnicy, daje wartość wytrzymałości która odpowiada wytrzymałości próbki walcowej o wymiarach $150 \mathrm{~mm}$ na $300 \mathrm{~mm}$.

$\mathrm{Na}$ podstawie przeprowadzonego badania wytrzymałości betonu na ściskanie określono średnią wytrzymałość czterech próbek na ściskanie, która wyniosła $32,75 \mathrm{MPa}$ (tabela 2). 


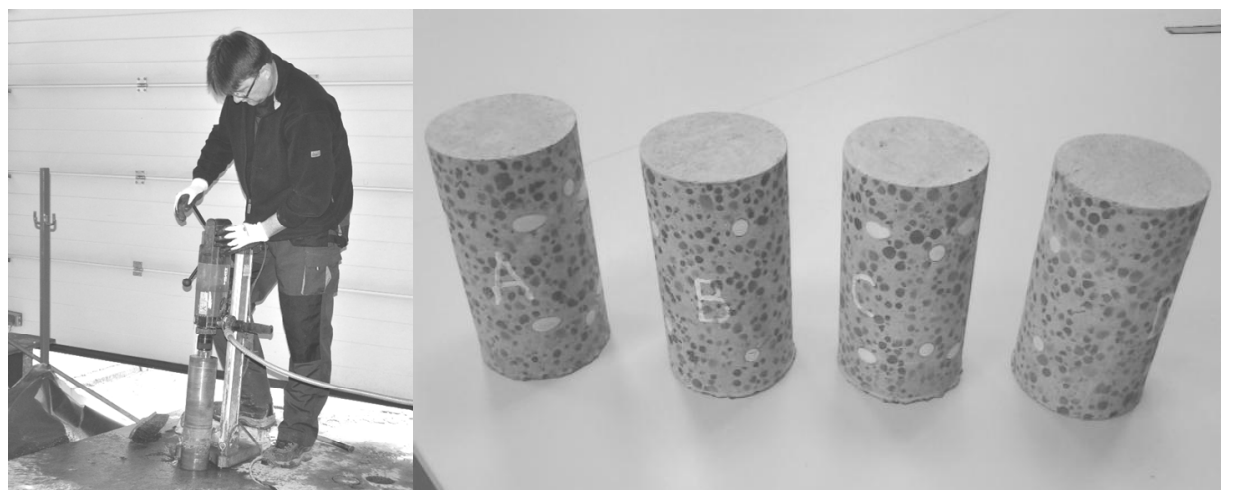

Rys. 2. Pobieranie próbek z modelu (po lewej) oraz próbki pobrane do badań (po prawej)

Fig. 2. Taking samples from M3 slab model (left) and the samples for testing (right)

Tabela 2. Wytrzymałość betonu na ściskanie uzyskana na podstawie badań

Table 2. The compressive strength of concrete according to test

\begin{tabular}{|c|c|c|}
\hline Symbol próbki & $\begin{array}{c}\text { Sila } \\
\text { niszcząca } \\
{[\mathbf{k N}]}\end{array}$ & $\begin{array}{c}\text { Wytrzymalość próbek na } \\
\text { ściskanie } \\
{[\mathbf{M P a}]}\end{array}$ \\
\hline $\mathrm{A}$ & 285,40 & 33,34 \\
\hline $\mathrm{B}$ & 280,17 & 32,73 \\
\hline $\mathrm{C}$ & 290,74 & 33,90 \\
\hline $\mathrm{D}$ & 265,83 & 31,05 \\
\hline Wartość średnia & 280,54 & 32,76 \\
\hline
\end{tabular}

Określona zgodnie z normą [18] charakterystyczna wartość wytrzymałości betonu na ściskanie na próbkach cylindrycznych wynosiła 25,76 MPa. Zgodnie $\mathrm{z}$ norma [20] wyznaczono pozostałe parametry betonu z uwzględnieniem gęstości betonu lekkiego:

- charakterystyczna wytrzymałość na ściskanie: $25,76 \mathrm{MPa}$;

- charakterystyczna wytrzymałość na rozciąganie: 2,46 MPa;

- moduł Younga: 25,94 GPa;

- odkształcenie graniczne: 3,31\%. 


\section{Badania statyczne płyt}

\subsection{Metodologia badań statycznych}

Badania statyczne przeprowadzono $\mathrm{w}$ dwóch schematach statycznych: schemat jednoprzęsłowy o rozpiętości 4,80 m (model M1) oraz schemat dwuprzęsłowy o rozpiętości przęseł 2,40 m (modele M2 i M3) (rys. 3). Rozpiętość w schemacie dwuprzęsłowym dostosowano do średniej wartości rozpiętości betonowych płyt pomostowych w mostach belkowych. Sposób oparcia płyt przedstawiono na rys. 4. Płyty poddane zostały kilkofazowemu obciążeniu statycznemu aż do zniszczenia.

Schemat M1:

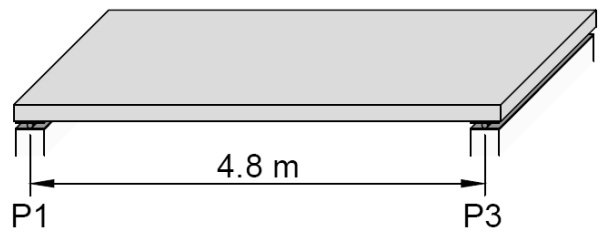

Schemat M2, M3:

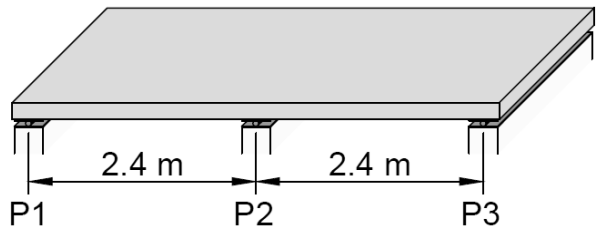

Rys. 3. Schematy badań M1, M2 (M3)

Fig. 3. Test scheme M1, M2 (M3)

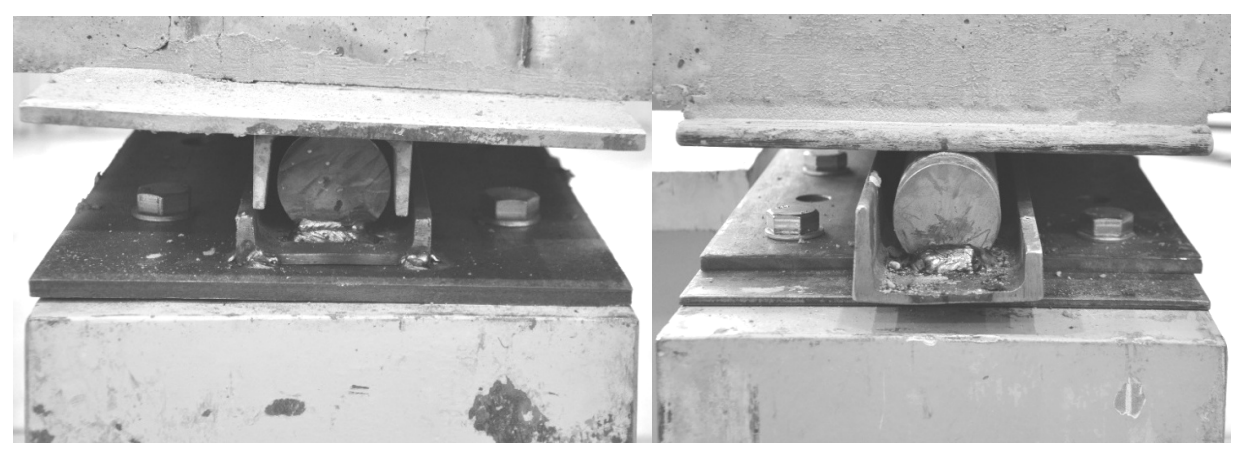

Rys. 4. Sposób oparcia płyt: łożysko nieprzesuwne (po lewej) i przesuwne (po prawej)

Fig. 4. Slab supports: pinned support (left) and roller support (right)

Obciążenie było generowane za pomocą siłownika hydraulicznego. W badaniach statycznych obciążenie zostało rozłożone na powierzchnię badanych płyt za pomocą belki trawersowej oraz podkładek stalowych o wymiarach $0,4 \times 0,4 \times 0,02 \mathrm{~m}$ (rys. 5). Sposób przyłożenia obciążenia symulował dwa modele obciążeniowe LM1 i LM2 płyt pomostowych w obiektach mostowych wg normy [19] (rys. 6). 


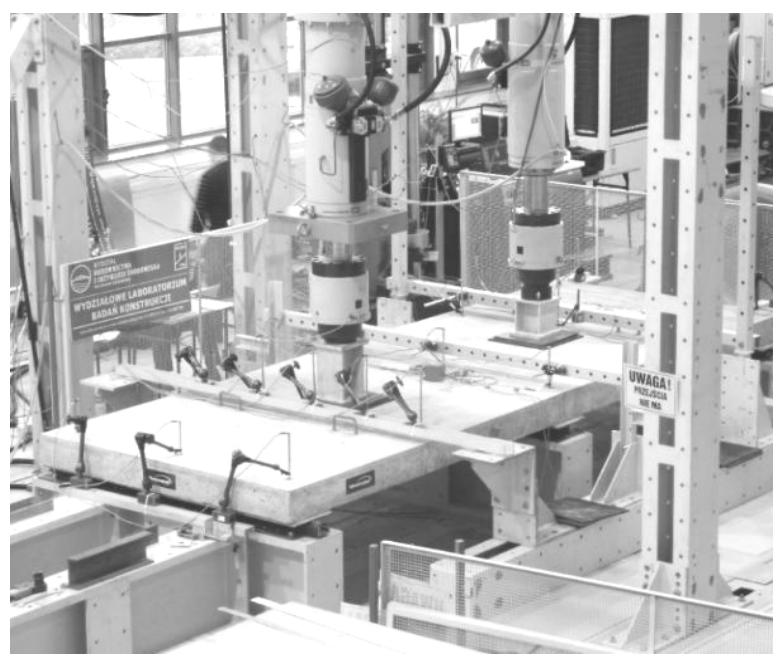

Rys. 5. Płyta na stanowisku badawczym

Fig. 5. The slab under testing

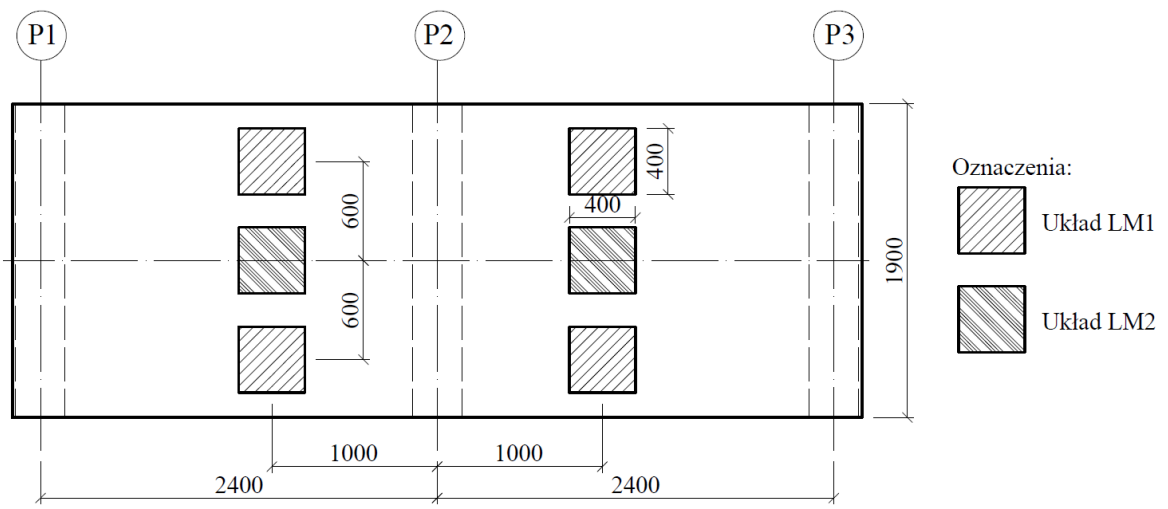

Rys. 6. Schematy obciążenia LM1 oraz LM2

Fig. 6. Loading schemes LM1 and LM2

W badaniach statycznych zastosowano dwa poziomy obciążenia modeli płyt pomostu: obciążenie charakterystyczne $\left(\mathrm{P}_{\mathrm{k}}\right)$, wywołujące charakterystyczną wartość momentu zginającego w płycie pod obciążeniem normowym wg [10] oraz obciążenie obliczeniowe $\left(\mathrm{P}_{\mathrm{d}}\right)$, wywołujące obliczeniową wartość momentu zginającego w modelu. Ostatnim cyklem było obciążenie płyt pomostu aż do zniszczenia. Właściwe obciążenie płyt poprzedzono cyklem wstępnym o wartości $50 \%$ obciążenia charakterystycznego $\left(0,5 \mathrm{P}_{\mathrm{k}}\right)$ w celu ułożenia i dopasowania płyt pomostu na stanowisku badawczym. Etapy obciążania płyt przedstawiono w tabeli 3 i w tabeli 4 odpowiednio dla modeli płyt M1 i M2. 
Tabela 3. Etapy oraz wartości obciążenia modelu M1

Table 3. The loading steps of the M1 slab model

\begin{tabular}{|c|c|c|c|c|}
\hline Etap & $\begin{array}{l}\text { Wartość ob- } \\
\text { ciążenia [kN] }\end{array}$ & $\begin{array}{c}\text { Liczba } \\
\text { cykli }\end{array}$ & $\begin{array}{c}\text { Uklad } \\
\text { obciążenia }\end{array}$ & Wartości obciążenia \\
\hline 1 & $\begin{array}{c}17,5 \\
(2 \times 8,75)\end{array}$ & 1 & \multirow{3}{*}{ LM1 } & $\begin{array}{c}50 \% \text { charakterystycznego } \\
\text { momentu zginającego } \\
\left(0,5 \mathrm{P}_{\mathrm{k}}\right)\end{array}$ \\
\hline 2 & $\begin{array}{c}34,9 \\
(2 \times 17,45)\end{array}$ & 3 & & $\begin{array}{c}\text { charakterystyczny moment } \\
\text { zginający } \\
\left(\mathrm{P}_{\mathrm{k}}\right) \\
\end{array}$ \\
\hline 3 & $\begin{array}{c}94,5 \\
(2 \times 47,25)\end{array}$ & 3 & & $\begin{array}{c}\text { obliczeniowy moment } \\
\text { zginający } \\
\left(\mathrm{P}_{\mathrm{d}}\right)\end{array}$ \\
\hline 4 & $\begin{array}{c}34,2 \\
(2 \times 17,10)\end{array}$ & 3 & \multirow{2}{*}{ LM2 } & $\begin{array}{c}\text { charakterystyczny moment } \\
\text { zginający } \\
\left(\mathrm{P}_{\mathrm{k}}\right)\end{array}$ \\
\hline 5 & $\begin{array}{c}93,0 \\
(2 \times 46,50)\end{array}$ & 3 & & $\begin{array}{c}\text { obliczeniowy moment } \\
\text { zginający } \\
\left(\mathrm{P}_{\mathrm{d}}\right) \\
\end{array}$ \\
\hline 6 & $\begin{array}{c}155,0 \\
(2 \times 77,85)\end{array}$ & 1 & \multirow{3}{*}{ LM1 } & \multirow{2}{*}{$\begin{array}{l}\text { obciążenie przejściowe (kon- } \\
\text { trolne) }\end{array}$} \\
\hline 7 & $\begin{array}{c}200,0 \\
(2 \times 100,00)\end{array}$ & 1 & & \\
\hline 8 & $\begin{array}{c}220,0 \\
(2 \times 110,00) \\
\end{array}$ & 1 & & obciążenie niszczące \\
\hline
\end{tabular}

Podczas badań mierzono przemieszczenia płyt oraz odkształcenia w betonie. Do pomiaru przemieszczeń pionowych zastosowano czujniki indukcyjne o bazie pomiarowej $100 \mathrm{~mm}$ zamontowane na uchwytach elektromagnetycznych. Pomiary przemieszczeń płyty M1 wykonano w 1/2 i 1/4 rozpiętości oraz kontrolnie nad podporami (łącznie 13 czujników przemieszczeń). W przypadku modelu M2 przemieszczenia rejestrowano w środku rozpiętości obu przęseł oraz kontrolnie nad podporami (łącznie 17 czujników przemieszczeń). Do pomiaru odkształceń betonu zastosowano elektrooporowe czujniki tensometryczne. Odkształcenia betonu dla modelu M1 mierzono w środku rozpiętości przęsła (górna i dolna powierzchnia płyty) oraz $\mathrm{w}$ miejscach przyłożenia obciążeń (1 m od środka płyty) na dolnej powierzchni płyty (łącznie 12 czujników odkształceń). Dla modelu M2 odkształcenia na górnej powierzchni płyty rejestrowano w przekrojach nad podporą środkową oraz na powierzchni dolnej w przekrojach przyłożenia obciążenia, tj. $1 \mathrm{~m}$ od środka płyty/podpory środkowej (łącznie 11 czujników odkształceń). Dodatkowo na każdym z etapów obciążenia rejestrowana była morfologia zarysowania i rozwój zniszczenia płyt. 
Tabela 4. Etapy oraz wartości obciążenia modelu M2

Table 4. The loading steps of the M2 slab model

\begin{tabular}{|c|c|c|c|c|}
\hline Etap & $\begin{array}{c}\text { Wartość } \\
\text { obciążenia } \\
{[\mathrm{kN}]} \\
\end{array}$ & $\begin{array}{l}\text { Liczba } \\
\text { cykli }\end{array}$ & $\begin{array}{c}\text { Układ } \\
\text { obciążenia }\end{array}$ & Wartości obciążenia \\
\hline 1 & $\begin{array}{c}77,8 \\
(2 \times 38,90)\end{array}$ & 1 & \multirow{3}{*}{ LM1 } & $\begin{array}{c}50 \% \text {, charakterystycznego } \\
\text { momentu zginającego } \\
\left(0,5 \mathrm{P}_{\mathrm{k}}\right)\end{array}$ \\
\hline 2 & $\begin{array}{c}155,5 \\
(2 \times 77,85)\end{array}$ & 3 & & $\begin{array}{c}\text { charakterystyczny moment } \\
\text { zginający } \\
\left(\mathrm{P}_{\mathrm{k}}\right)\end{array}$ \\
\hline 3 & $\begin{array}{c}324,0 \\
(2 \times 162,00)\end{array}$ & 3 & & $\begin{array}{c}\text { obliczeniowy moment } \\
\text { zginający } \\
\left(\mathrm{P}_{\mathrm{d}}\right) \\
\end{array}$ \\
\hline 4 & $\begin{array}{c}300,0 \\
(2 \times 150,00)\end{array}$ & 3 & LM2 & $\begin{array}{c}\text { obliczeniowy moment } \\
\text { zginający } \\
\left(\mathrm{P}_{\mathrm{d}}\right)\end{array}$ \\
\hline 5 & $\begin{array}{c}450,0 \\
(2 \times 225,00)\end{array}$ & 1 & \multirow{4}{*}{ LM1 } & \multirow{3}{*}{$\begin{array}{l}\text { obciążenie przejściowe (kon- } \\
\text { trolne) }\end{array}$} \\
\hline 6 & $\begin{array}{c}600,0 \\
(2 \times 300,00) \\
\end{array}$ & 2 & & \\
\hline 7 & $\begin{array}{c}810,0 \\
(2 \times 405,00)\end{array}$ & 2 & & \\
\hline 8 & $\begin{array}{c}880,0 \\
(2 \times 440,00)\end{array}$ & 1 & & obciążenie niszczące \\
\hline
\end{tabular}

\subsection{Główne wyniki badań statycznych}

Na rys. 7 i 8 przedstawiono wykresy „obciążenie - przemieszczenie” do poziomu obciążenia obliczeniowego $\mathrm{P}_{\mathrm{d}} \mathrm{W}$ środku rozpiętości przęseł odpowiednio dla modeli M1 i M2. Wartość obciążenia podana na wykresach jest sumą sił z obu siłowników. Wartości ugięć na długości płyt (w osi podłużnej) dla trzech etapów obciążenia $\left(0,5 \mathrm{P}_{\mathrm{k}}, \mathrm{P}_{\mathrm{k}}\right.$ i $\left.\mathrm{P}_{\mathrm{d}}\right)$ przedstawiają rys. 9 i 10 . Wykresy zależności „obciążenie - odkształcenie betonu (rozciąganie)” do poziomu obciążenia charakterystycznego $\mathrm{P}_{\mathrm{k}}$ przedstawiono na rys. 11 i 12 odpowiednio dla modeli M1 i M2. Dla modelu M2 wykres przedstawia odkształcenia betonu nad podporą środkową mierzone w środku płyty, natomiast w przypadku płyty M1 przedstawiono odkształcenia betonu $\mathrm{w}$ środku rozpiętości przęsła na krawędzi płyty, ze względu na awarie pozostałych czujników odkształceń w tym przekroju. Na rys. 13 i 14 przedstawiono morfologię rozwoju rys dla obu modeli płyt na poziomach obciążenia: $0,5 \mathrm{P}_{\mathrm{k}}, \mathrm{P}_{\mathrm{k}}$ i $\mathrm{P}_{\mathrm{d}}$. 


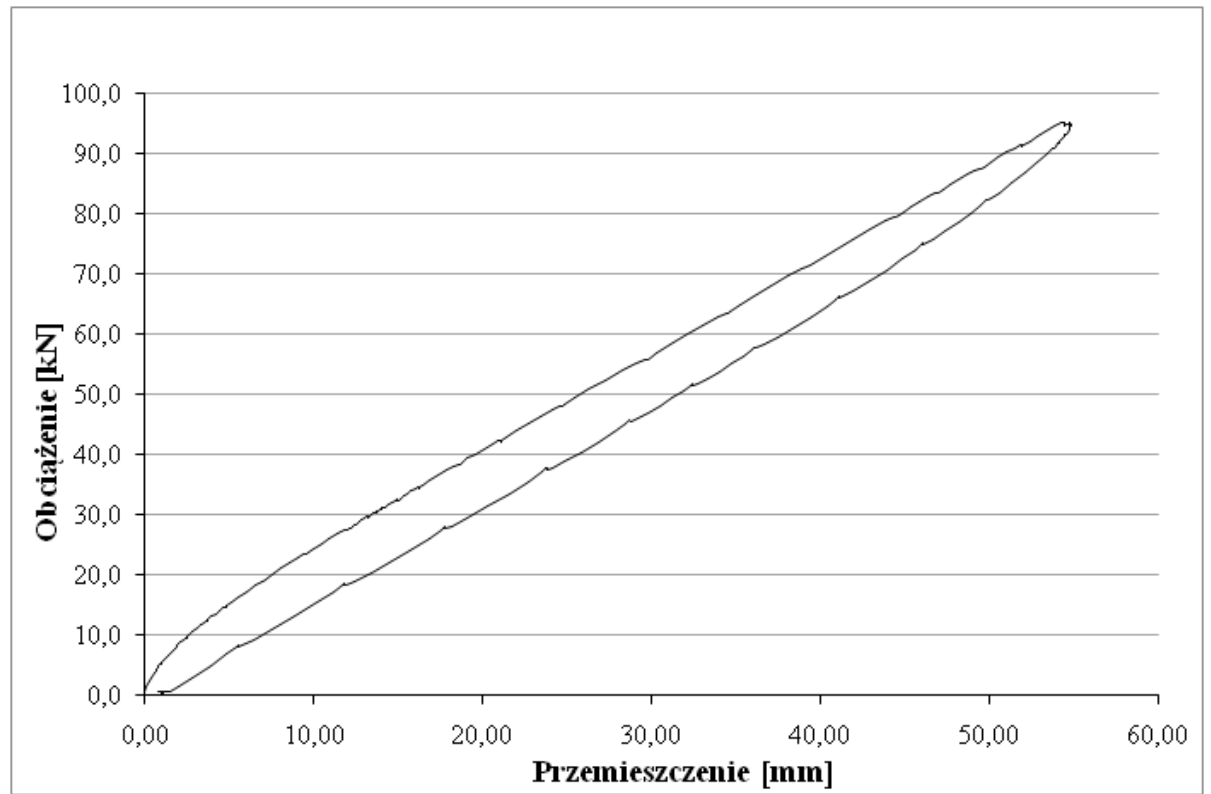

Rys. 7. Przemieszczenie $w$ środku rozpiętości płyty $M 1$ do poziomu obciążenia $P_{d}$

Fig. 7. Mid-span displacement for M1slab model to the $P_{d}$ level

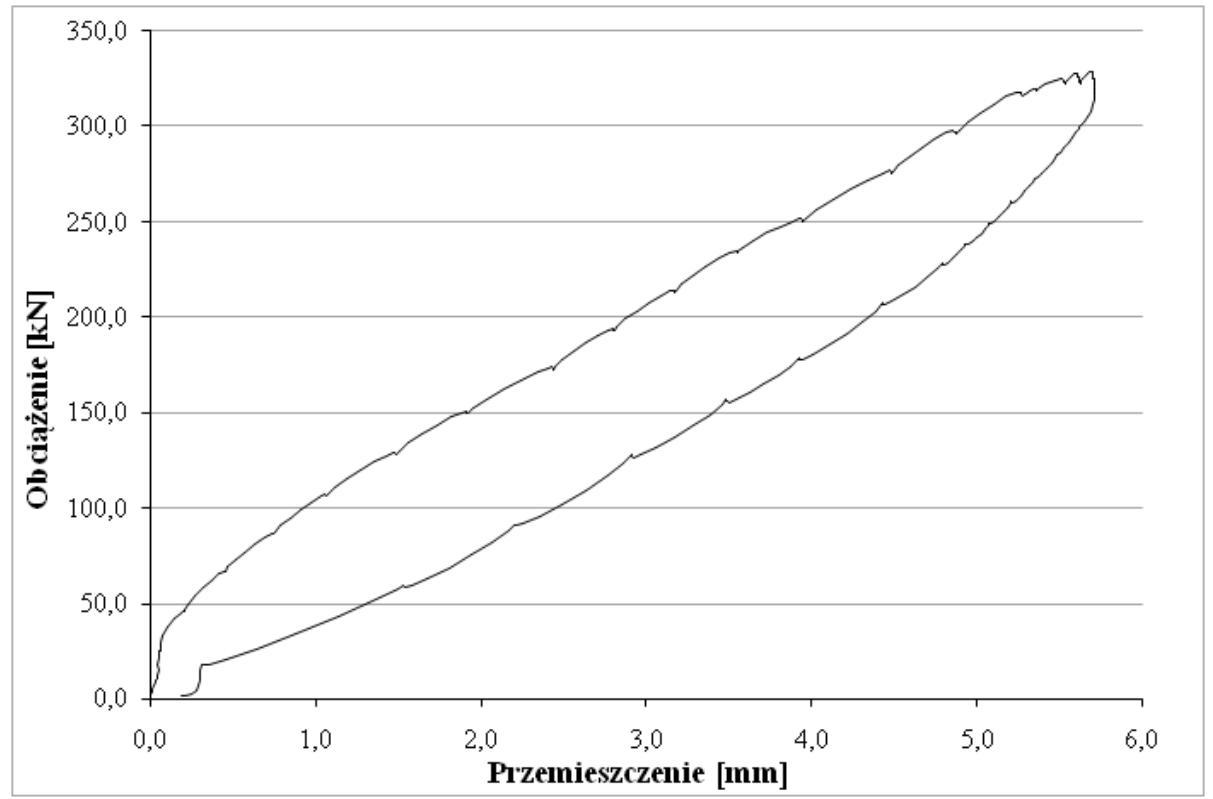

Rys. 8. Przemieszczenia w środku rozpiętości przęsła P2-P3 płyty M2 dla poziomu obciążenia $\mathrm{P}_{\mathrm{d}}$

Fig. 8. Mid-span P2-P3 displacement for M2 slab model to the level $\mathrm{P}_{\mathrm{d}}$ 


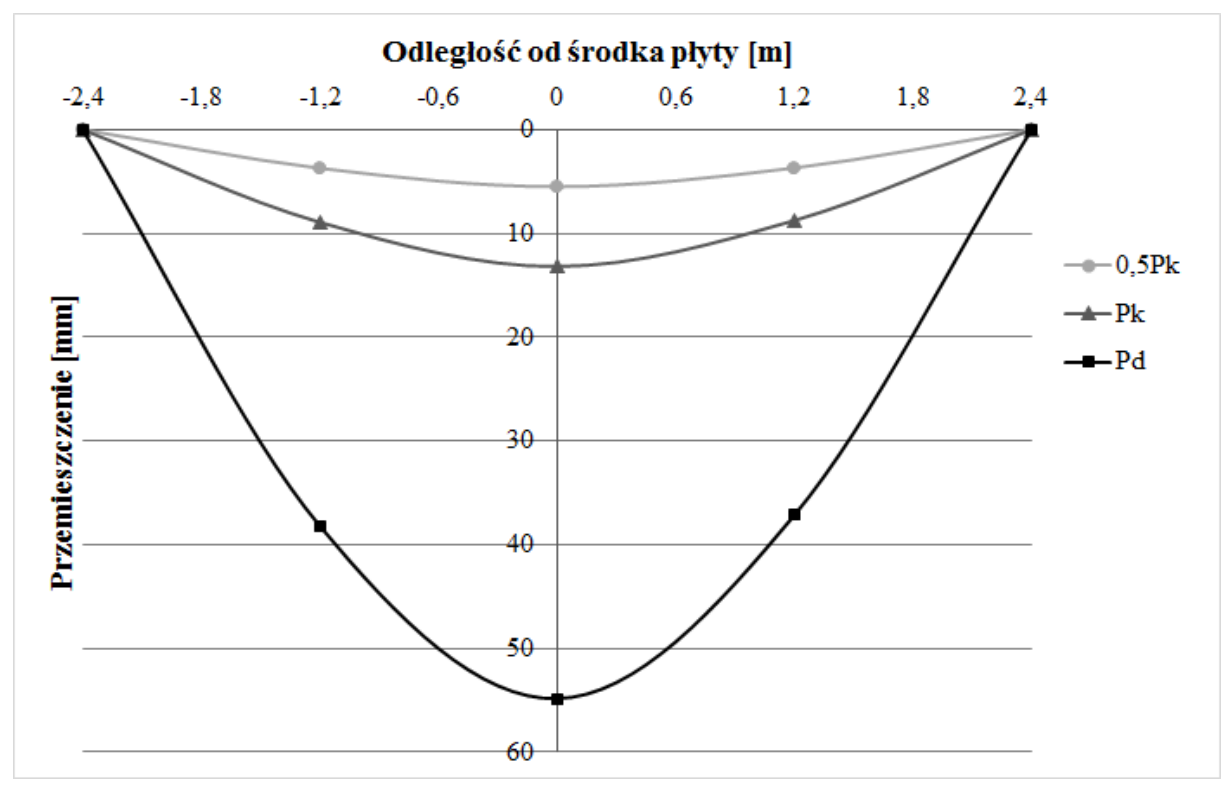

Rys. 9. Porównanie ugięć w środku rozpiętości płyty M1 na trzech poziomach obciążenia

Fig. 9. Comparison of M1 slab model mid-span deflections for three load levels

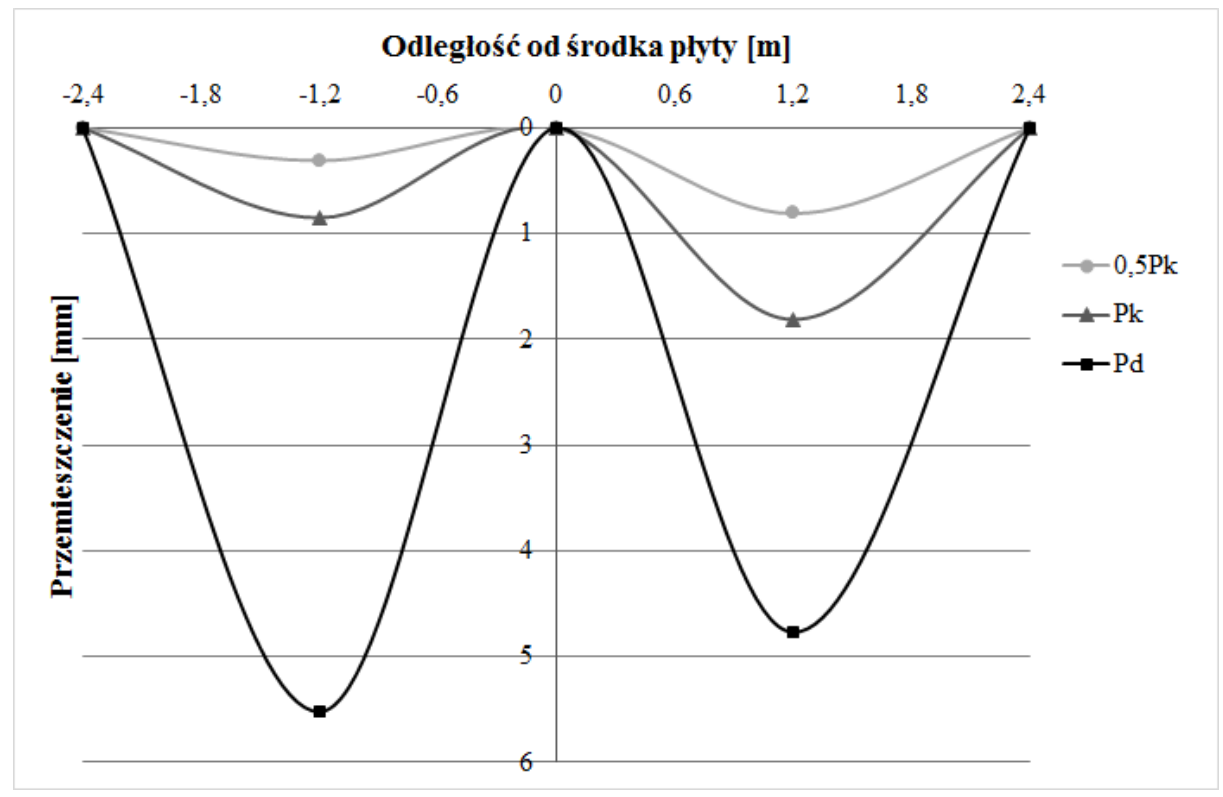

Rys. 10. Porównanie ugięć w środkach rozpiętości przęseł płyty M2 na trzech poziomach obciążenia

Fig. 10. Comparison of M2 slab model mid-span deflections for three load levels 


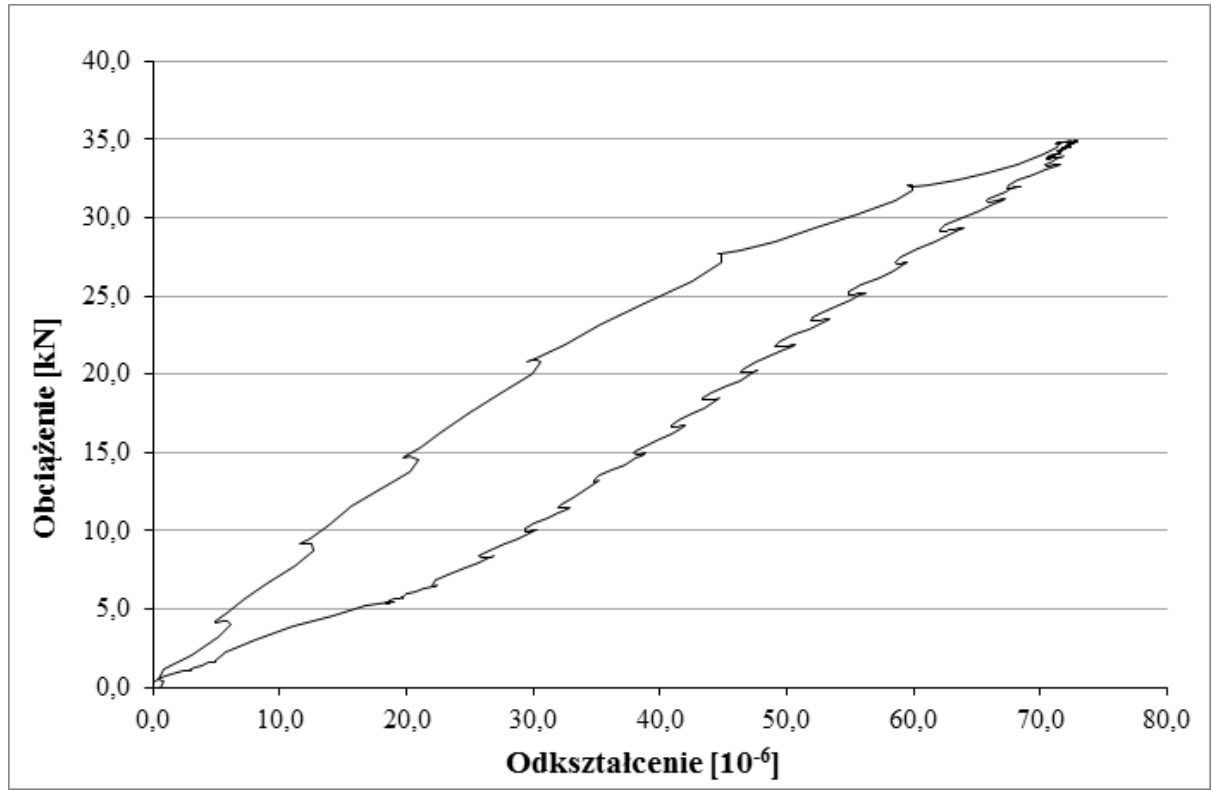

Rys. 11. Odkształcenie betonu (rozciąganie) w środku rozpiętości płyty M1 do poziomu obciążenia $P_{k}$

Fig. 11. Mid-span concrete strains (tension) for M1 slab model to the level $\mathrm{P}_{\mathrm{k}}$

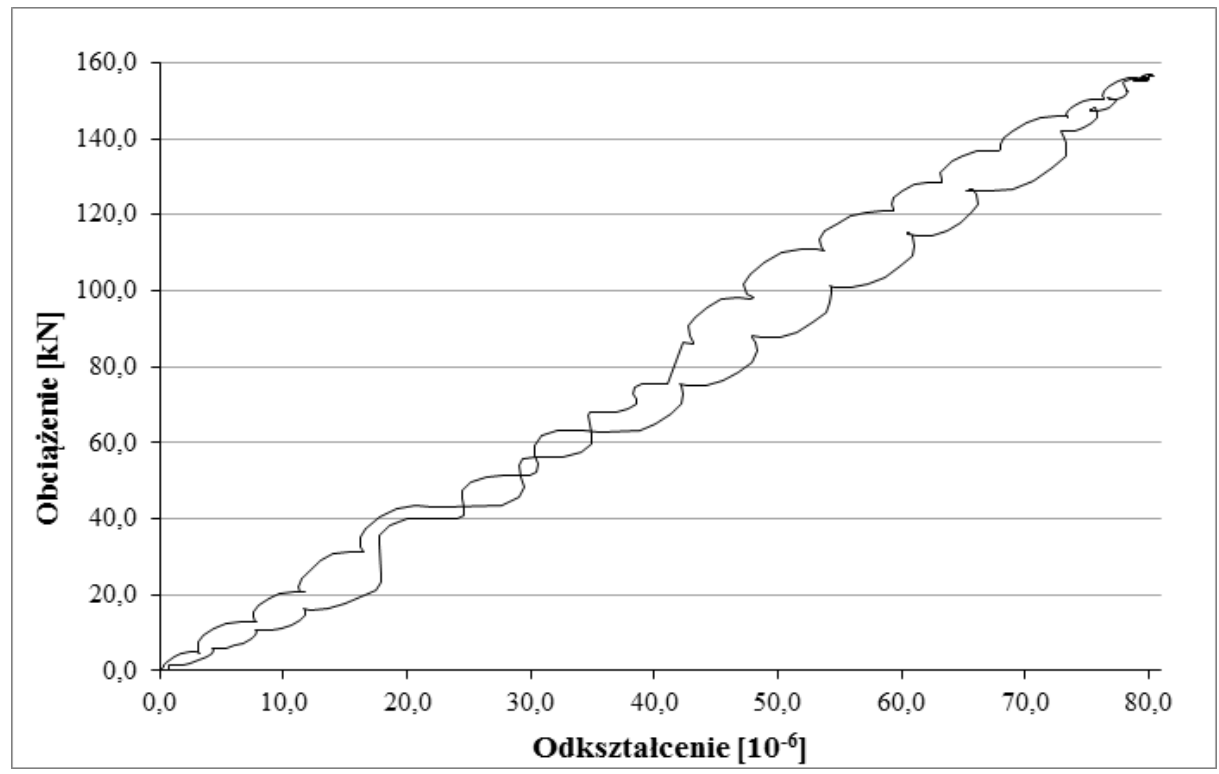

Rys. 12. Odkształcenie betonu (rozciąganie) nad podporą $\mathrm{P} 2$ płyty $\mathrm{M} 2$ do poziomu obciążenia $\mathrm{P}_{\mathrm{k}}$

Fig. 12. Concrete strains (tension) on support P2 of the M2 slab model to the level $\mathrm{P}_{\mathrm{k}}$ 

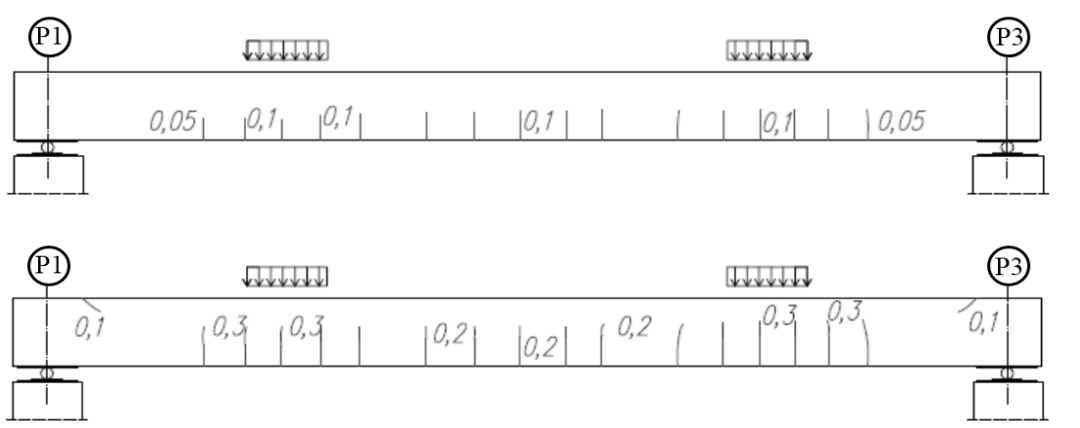

$\mathrm{P}_{\mathrm{k}}$

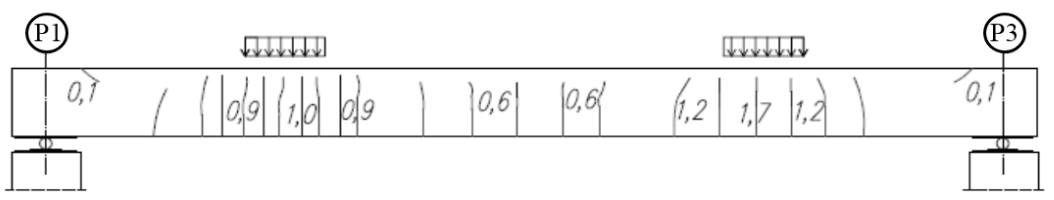

$\mathrm{P}_{\mathrm{d}}$

Rys. 13. Morfologia rys dla modelu M1 na trzech poziomach obciążenia

Fig. 13. The crack patterns for M1 slab model for three load levels
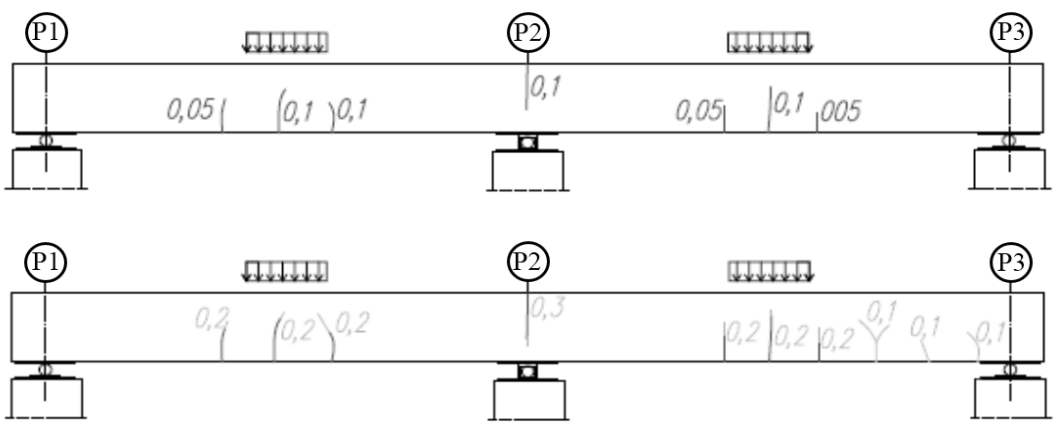

$\mathrm{P}_{\mathrm{k}}$

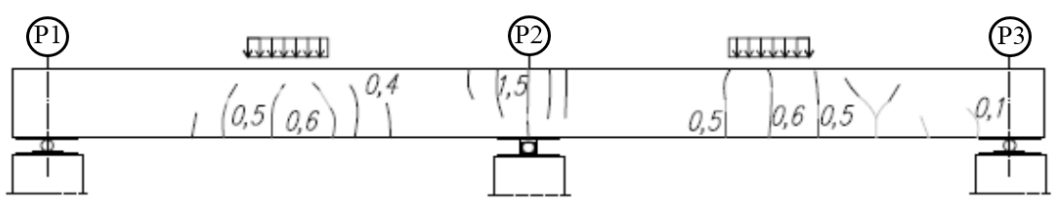

$\mathrm{P}_{\mathrm{d}}$

Rys. 14. Morfologia rys dla modelu M2 na trzech poziomach obciążenia

Fig. 14. The crack patterns for M2 slab model for three load levels

Płyta M1 o schemacie jednoprzęsłowym uległa zniszczeniu w wyniku zginania przy sumarycznym obciążeniu $\mathrm{z}$ obu siłowników $\mathrm{P}_{\mathrm{ul}}=220 \mathrm{kN}$ (rys. 15). Płyta o schemacie dwuprzęsłowym M2 została zniszczona w wyniku ścinania przy całkowitym obciążeniu $\mathrm{P}_{\mathrm{ul}}=880 \mathrm{kN}$. Ścięcie betonu nastąpiło $\mathrm{w}$ przekroju pod punktem przyłożenia siły i propagowało w kierunku podpory środkowej (rys. 16). 


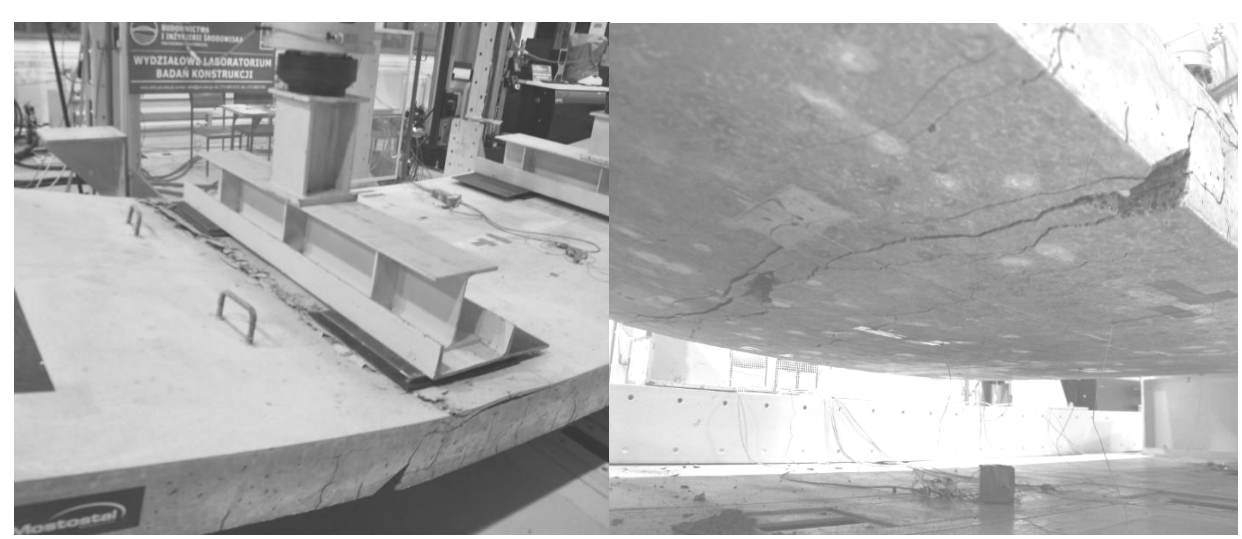

Rys. 15. Zniszczenie płyty M1 w wyniku zginania

Fig. 15. Flexural failure of M1 slab model

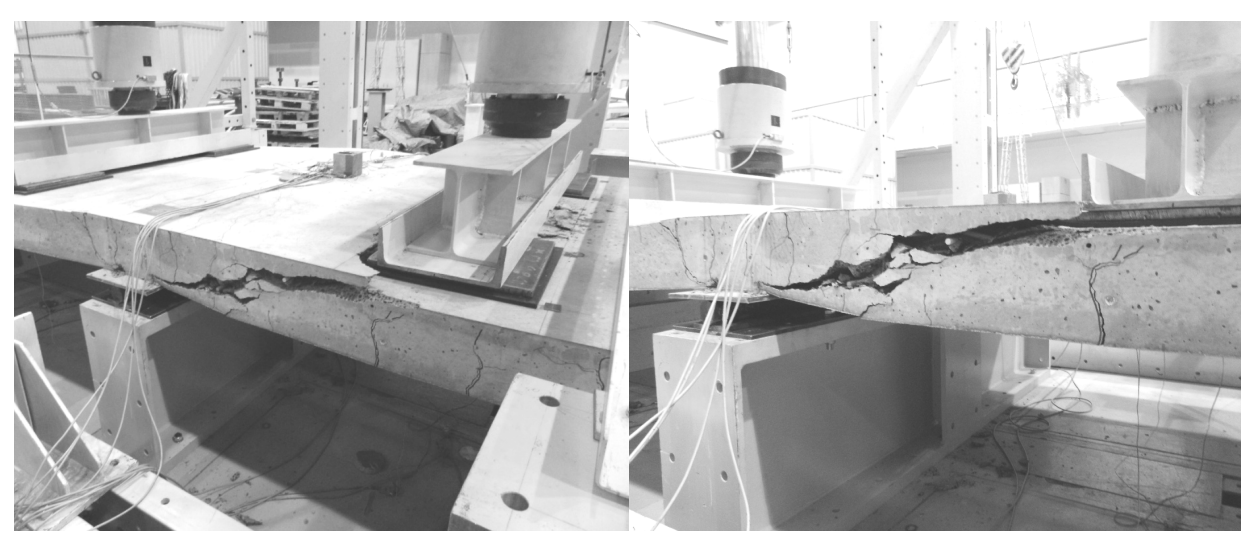

Rys. 16. Zniszczenie płyty M2 w wyniku ścięcia betonu

Fig. 16. Shear failure of M2 slab model

\subsection{Analiza wyników badań statycznych}

Na podstawie uzyskanych wartości obciążenia niszczącego w poszczególnych modelach obciążenia wyznaczono rzeczywiste (eksperymentalne) nośności graniczne. Doświadczalna nośność na zginanie płyty M1 (schemat jednoprzęsłowy) wyniosła $91,0 \mathrm{kNm} / \mathrm{m}$, natomiast nośność na ścinanie płyty M2 wyniosła $148,8 \mathrm{kN} / \mathrm{m}$. W przypadku modelu M2 przy złożeniu sprężystej pracy płyty przy wyznaczeniu sił wewnętrznych, dla obciążenia niszczącego uzyskano nad podporą środkową wartość momentu zginającego wynoszącą $106,2 \mathrm{kNm} / \mathrm{m}$. Pomimo uzyskania większej wartości momentu zginającego niż w przypadku płyty M1 zniszczenie płyty M2 nastąpiło w wyniku ścinania, co wynika $\mathrm{z}$ redystrybucji momentu zginającego ze względu 
na redukcję sztywności w wyniku zarysowania (w rzeczywistości wartość momentu nad podporą była mniejsza niż wyznaczona przy założeniu sprężystej pracy płyty).

Na podstawie wytycznych [2] wyznaczono wartość nośności nominalnej na zginanie i na ścinanie na $1 \mathrm{~m}$ szerokości płyty [23]. Porównanie uzyskanych wartości z wynikami badań przedstawiono w tabeli 5 .

Tabela 5. Porównanie wyników obliczeń nośności z wynikami badań doświadczalnych

Table 5. Comparison of calculated carrying capacity and experimental data

\begin{tabular}{|c|c|c|c|}
\hline \multirow{2}{*}{ Rodzaj nośności } & $\begin{array}{c}\text { Nośność wg } \\
\text { ACI [2] }\end{array}$ & Wyniki badań & Porównanie \\
\cline { 2 - 4 } & $\mathbf{( a )}$ & $\mathbf{( b )}$ & $\mathbf{( b ) / ( a )}$ \\
\hline Nośność na zginanie $[\mathrm{kNm} / \mathrm{m}]$ & 92,6 & $91,0(\mathrm{M} 1)$ & 0,98 \\
\cline { 3 - 4 } & 55,1 & $106,2(\mathrm{M} 2)^{*}$ & 1,15 \\
\hline Nośność na ścinanie $[\mathrm{kN} / \mathrm{m}]$ & $148,8(\mathrm{M} 2)^{*}$ & 2,70 \\
\hline * zniszczenie płyty w wyniku ścinania \\
\hline
\end{tabular}

Porównując wyniki obliczeń z badaniami doświadczalnymi można stwierdzić bardzo dobrą zgodność między wartościami nośności na zginanie dla modelu M1. Nośność na ścinanie uzyskana na podstawie badania płyty M2 jest ponad dwukrotnie wyższa niż nośność uzyskana na podstawie obliczeń. Problem szacowania nośności na ścinanie elementów betonowych zbrojonych prętami kompozytowymi jest szeroko opisany w literaturze [12], [24]. Przeprowadzone badania wykazały konieczność dalszych prac nad tym zagadnieniem.

Na podstawie wyników badań doświadczalnych wyznaczono globalny zapas bezpieczeństwa w stanach granicznych nośności (SGN), definiowany jako stosunek doświadczalnej nośności na zginanie i ścinanie do projektowanego (docelowego) momentu zginającego w płycie pomostu. Wartości sił wewnętrznych na poszczególnych poziomach obciążenia przedstawiono w tabeli 6 . Wartość tak definiowanego współczynnika bezpieczeństwa płyty pomostu wyniosła powyżej 4,0 co daje satysfakcjonujący wynik w aspekcie bezpieczeństwa obiektu mostowego.

Tabela 6. Porównanie charakterystycznego i granicznego (doświadczalnego) momentu zginającego w SGN

Table 6. Comparison of characteristic and ultimate (experimental) bending moments for ULS

\begin{tabular}{|c|c|c|c|}
\hline \multirow{2}{*}{$\begin{array}{c}\text { Poziom ob- } \\
\text { ciążenia }\end{array}$} & Schemat M1 & \multicolumn{2}{|c|}{ Schemat M2 } \\
\cline { 3 - 4 } & & Przęsło & $\begin{array}{c}\text { Podpora } \\
\text { środkowa }\end{array}$ \\
\cline { 2 - 4 } & & $1 \mathrm{kNm} / \mathrm{m}]$ \\
\hline $\mathrm{P}_{\mathrm{k}}$ & 22,8 & 64,0 & 21,2 \\
\hline $\mathrm{P}_{\mathrm{ul}}$ & 91,0 & 5,25 & 106,2 \\
\hline $\mathrm{P}_{\mathrm{ul}} / \mathrm{P}_{\mathrm{k}}$ & 4,0 & & 5,0 \\
\hline
\end{tabular}


Analogiczną ocenę płyty pomostu wykonano dla stanu granicznego użytkowalności (SGU). W tym celu porównano wartości maksymalnych ugięć, odkształceń (rozciąganie) i rozwartości rys z przyjętymi wartościami dopuszczalnymi (tabela 7). Za dopuszczalne ugięcie płyt przyjęto warunek $1 / 250$ zgodnie z normą [20]. Za dopuszczalną wartość odkształceń rozciągających w betonie przyjęto wartość odpowiadającą 5\% kwantylowi wytrzymałości betonu na rozciąganie. Dopuszczalna wartość rozwartości rys została przyjęta według wytycznych [2] .

Na podstawie porównania wartości doświadczalnych dla poziomu obciążenia $\mathrm{P}_{\mathrm{k}} \mathrm{z}$ przyjętymi wartościami granicznymi stwierdzono spełnienie warunków stanów granicznych użytkowalności w zakresie ugięć i rozwartości rys. W przypadku odkształceń betonu uzyskane $\mathrm{w}$ badaniach doświadczalnych wartości są zbliżone lub przekraczają wartości dopuszczalne. Wynika to z przyjęcia wartości doświadczalnych dla punktów pomiarowych przy krawędzi płyty.

Tabela 7. Porównanie wartości doświadczalnych z wartościami dopuszczalnymi w SGU

Table 7. Comparison of experimental and allowable values for SLS

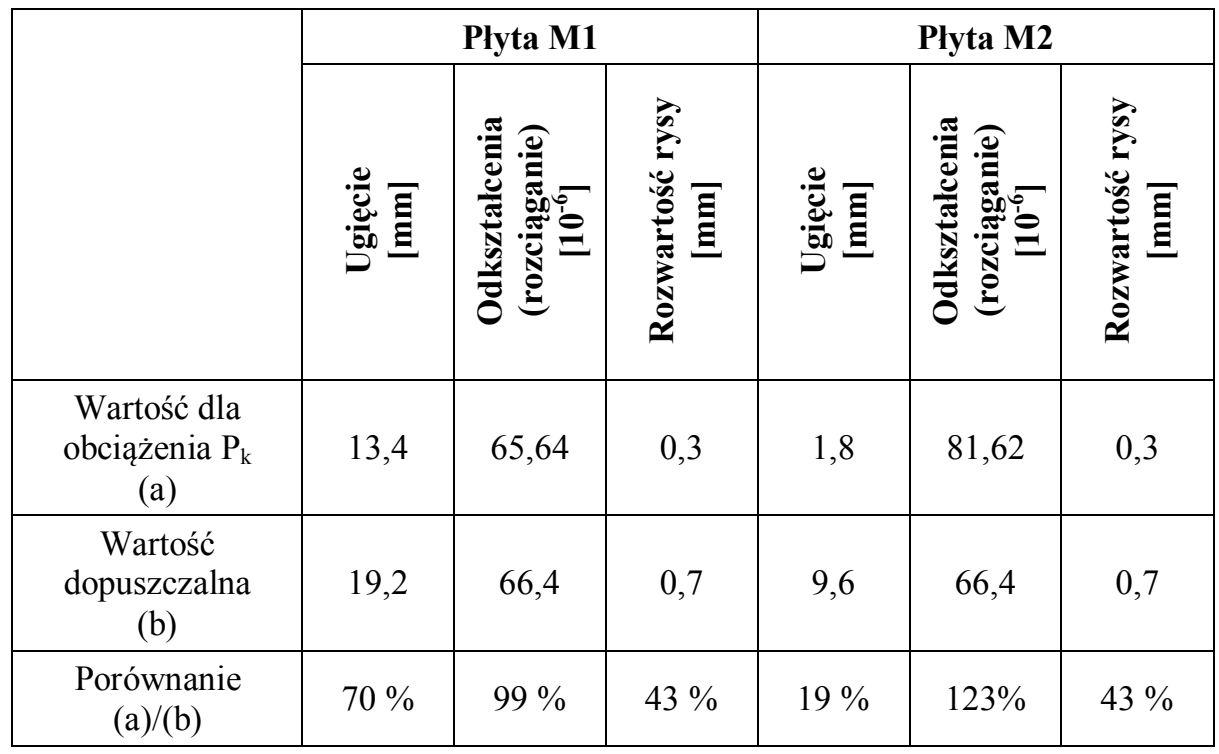

\section{Badania zmęczeniowe}

\subsection{Metodologia badań zmęczeniowych}

Obciążenie zmęczeniowe zostało przeprowadzone na modelu badawczym M3 w schemacie dwuprzęsłowym $(2 \times 2,40 \mathrm{~m})$. Podczas badań przykładane obciążenie wywoływało $\mathrm{w}$ płycie moment zginający równy momentowi od przejazdu pojazdu normowego FLM1 z obciążeniem $210 \mathrm{kN}$ na pojedynczą 
oś wg [19]. Schemat obciążenia modelem FLM1 odpowiadał sposobowi przykładania obciążenia LM1 (rys. 6).

Poszczególne cykle obciążenia modelu M3 opisano w tabeli 8. Po czterech cyklach statycznych na poziomie $0,5 \mathrm{P}_{\mathrm{k}}$ i $\mathrm{P}_{\mathrm{k}}$ przystąpiono do badań zmęczeniowych i obciążono model M3 siłami o zakresie zmienności $\Delta \mathrm{F}=200,0 \mathrm{kN}$ $(2 \times 100,0 \mathrm{kN})$, przy wartościach $\mathrm{F}_{\max }=222,2 \mathrm{kN}(2 \times 111,1 \mathrm{kN})$ oraz $\mathrm{F}_{\min }=22,2 \mathrm{kN}(2 \times 11,1 \mathrm{kN})$. Obciążenie cykliczne było przykładane $\mathrm{z}$ częstotliwością $2 \mathrm{~Hz}$ (do 500 tys. cykli) i 1,5 Hz (do zniszczenia) oraz przy stałej opisującej niesymetryczność cyklu $\mathrm{R}=0,1$. Liczba, rodzaj oraz rozmieszczenie czujników przemieszczeń i odkształceń w modelu M3 podczas badań zmęczeniowych była identyczna jak w modelu M2.

Tabela 8. Etapy oraz wartości obciążenia modelu M3 podczas badania zmęczeniowego

Table 8 . The loading steps of the M3 slab model during fatigue test

\begin{tabular}{|c|c|c|c|c|}
\hline Etap & $\begin{array}{l}\text { Wartość ob- } \\
\text { ciążenia [kN] }\end{array}$ & $\begin{array}{l}\text { Liczba } \\
\text { cykli }\end{array}$ & $\begin{array}{c}\text { Uklad } \\
\text { obciążenia }\end{array}$ & Wartości obciążenia \\
\hline 1 & $\begin{array}{c}77,8 \\
(2 \times 38,90)\end{array}$ & 1 & \multirow{6}{*}{$\begin{array}{l}\text { FLM1 } \\
\text { (LM1) }\end{array}$} & $\begin{array}{c}50 \% \text { charakterystycznego } \\
\text { momentu zginającego } \\
\left(0,5 \mathrm{P}_{\mathrm{k}}\right)\end{array}$ \\
\hline 2 & $\begin{array}{c}155,5 \\
(2 \times 77,80)\end{array}$ & 3 & & $\begin{array}{c}\text { charakterystyczny moment } \\
\text { zginający } \\
\left(\mathrm{P}_{\mathrm{k}}\right)\end{array}$ \\
\hline 3 & $\begin{array}{l}\Delta \mathrm{F}=200,0(2 \\
\quad \times 100,00)\end{array}$ & 500 tys. & & $\begin{array}{c}\text { obciążenie pojazdem } \\
\text { zmęczeniowym FLM1 } \\
\left(\mathrm{P}_{\mathrm{FLM} 1}\right)\end{array}$ \\
\hline 4 & $\begin{array}{c}155,5 \\
(2 \times 77,80)\end{array}$ & 3 & & $\begin{array}{c}\text { charakterystyczny moment } \\
\text { zginający } \\
\left(\mathrm{P}_{\mathrm{k}}\right)\end{array}$ \\
\hline 5 & $\begin{array}{l}\Delta \mathrm{F}=200,0(2 \\
\quad \times 100,00)\end{array}$ & $\begin{array}{l}481,5 \\
\text { tys. }\end{array}$ & & $\begin{array}{c}\text { obciążenie pojazdem } \\
\text { zmęczeniowym FLM1 } \\
\left(\mathrm{P}_{\mathrm{FLM1}}\right)\end{array}$ \\
\hline 6 & $\begin{array}{c}420 \\
(2 \times 210,00)\end{array}$ & 1 & & $\begin{array}{c}\text { wyczerpanie } \\
\text { nośności zmęczeniowej }\end{array}$ \\
\hline
\end{tabular}

\subsection{Główne wyniki badań zmęczeniowych}

Główną ocenę globalnego zachowania modelu M3 pod obciążeniem zmęczeniowym wykonano na podstawie zmian przemieszczeń w czasie oraz stopnia rozwoju zarysowania płyty. Zmiany przemieszczeń w środku rozpiętości przęseł płyty oceniano na podstawie wartości przemieszczeń tłoka siłownika (D). Na rys. 17 przedstawiono porównanie wartości maksymalnego przemieszczenia tłoka siłowników $\left(\mathrm{D}_{\max }\right)$, minimalnego przemieszczenia tłoka 
$\left(\mathrm{D}_{\text {min }}\right)$, wartość średnią $\left(\mathrm{D}_{\mathrm{sr}}\right)$ oraz amplitudę przemieszczeń $\left(\mathrm{D}_{\mathrm{amp}}\right)$ dla przęsła P1-P2 modelu M3. Przemieszczenie $D_{\max }$ odpowiada maksymalnej sile obciążenia zmęczeniowego $\mathrm{F}_{\max }=111,1 \mathrm{kN}$, a przemieszczenie $\mathrm{D}_{\min }$ minimalnej wartości siły $\mathrm{F}_{\text {min }}=11,1 \mathrm{kN}$. W tabeli 9 przedstawiono ilościowo propagację rys w kolejnych cyklach obciążenia zmęczeniowego.

Po 980,5 tys. cyklach obciążenia odnotowano znaczny wzrost amplitudy przemieszczeń tłoka siłowników (rys. 17). Średnia wartość przemieszczenia tłoka siłownika w przęśle P2-P3 wyniosła $16 \mathrm{~mm}$, a w przęśle P1-P2 aż $50 \mathrm{~mm}$. Ze względu na tak duże wartości przemieszczeń oraz znaczną różnicę średnich przemieszczeń pomiędzy przęsłami $(34 \mathrm{~mm})$, jak również na podstawie oględzin zarysowania modelu M3 stwierdzono zniszczenie zmęczeniowe płyty pomostu. Główną przyczyną nagłych i znaczących przyrostów przemieszczeń była utrata przyczepności prętów kompozytowych do betonu (rys. 18). Zjawisko to można uznać zatem za przyczyną zniszczenia zmęczeniowego płyty i utraty jej nośności.

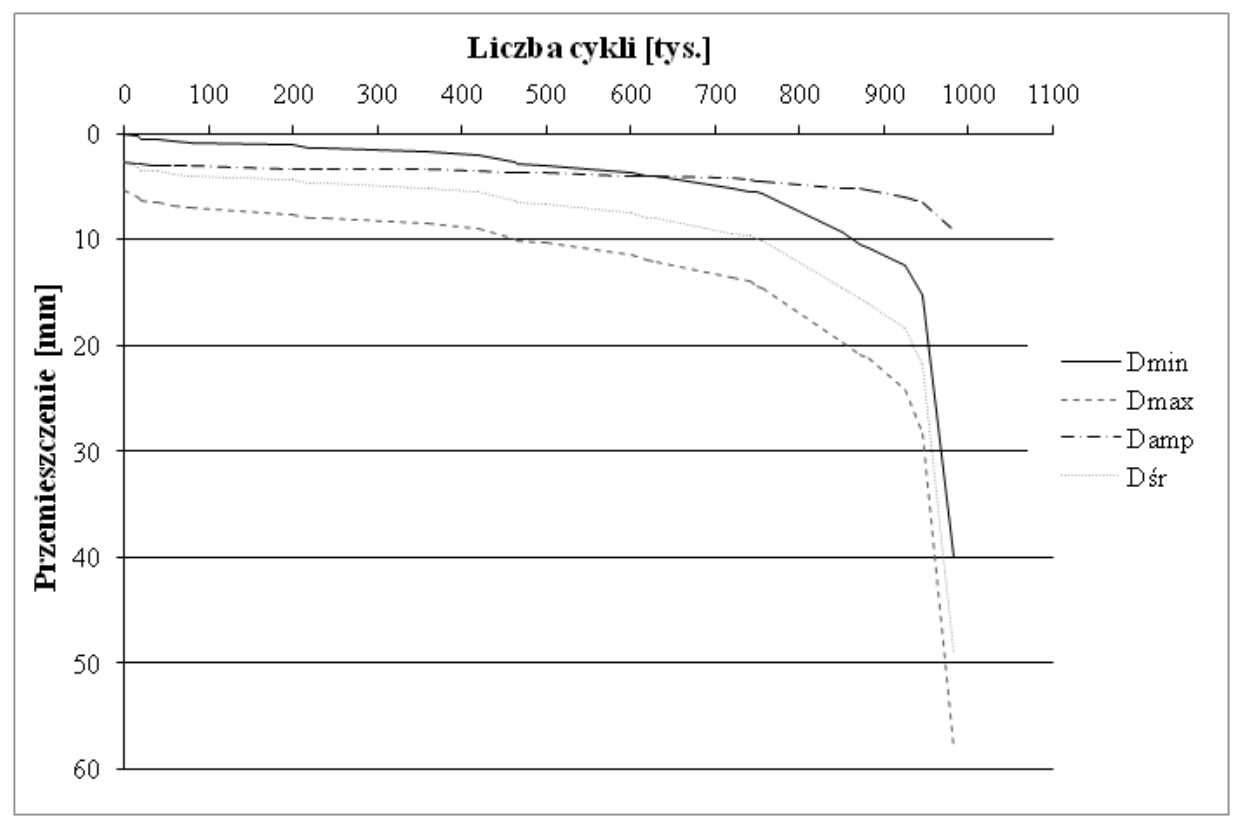

Rys. 17. Globalne zachowanie się modelu M3 podczas badania zmęczeniowego, przęsło P1-P2

Fig. 17. The global behavior of the M3 slab model during fatigue test, span P1-P2 
Tabela 9. Propagacja rozwartości rys w kolejnych cyklach obciążenia zmęczeniowego

Table 9. Propagation of cracks width in fatigue load test

\begin{tabular}{|c|c|c|c|c|c|c|c|}
\hline \multirow{3}{*}{$\begin{array}{l}\text { Liczba } \\
\text { cykli } \\
\text { [tys.] }\end{array}$} & \multirow{3}{*}{$\begin{array}{c}\text { Wartość } \\
\text { graniczna } \\
\text { [mm] } \\
\text { (a) }\end{array}$} & \multicolumn{6}{|c|}{ Szerokość rozwarcia rysy [mm] } \\
\hline & & \multicolumn{2}{|c|}{ Przęsło P1-P2 } & \multicolumn{2}{|c|}{$\begin{array}{c}\text { Podpora } \\
\text { środkowa P2 }\end{array}$} & \multicolumn{2}{|c|}{ Przęsło P2-P3 } \\
\hline & & $\begin{array}{l}\text { Pomiar } \\
\text { (b) }\end{array}$ & $\begin{array}{l}(\mathbf{b} / \mathbf{a}) \\
{[\%]}\end{array}$ & $\begin{array}{l}\text { Pomiar } \\
\text { (c) }\end{array}$ & $\begin{array}{l}\text { (c/a) } \\
{[\%]}\end{array}$ & $\begin{array}{l}\text { Pomiar } \\
\text { (d) }\end{array}$ & $\begin{array}{c}(\mathrm{d} / \mathrm{a}) \\
{[\%]}\end{array}$ \\
\hline 1 & 0,7 & 0,2 & 28,6 & 0,5 & 71,4 & 0,2 & 28,6 \\
\hline 8 & 0,7 & 0,6 & 85,7 & 0,9 & 128,6 & 0,6 & 85,7 \\
\hline 20 & 0,7 & 0,7 & 100,0 & 1,4 & 200,0 & 0,8 & 114,3 \\
\hline 40 & 0,7 & 0,9 & 128,6 & 1,6 & 228,6 & 1,0 & 142,9 \\
\hline 220 & 0,7 & 1,1 & 157,1 & 1,7 & 242,9 & 1,0 & 142,9 \\
\hline 480 & 0,7 & 1,7 & 242,9 & 2,0 & 285,7 & 1,2 & 171,4 \\
\hline
\end{tabular}

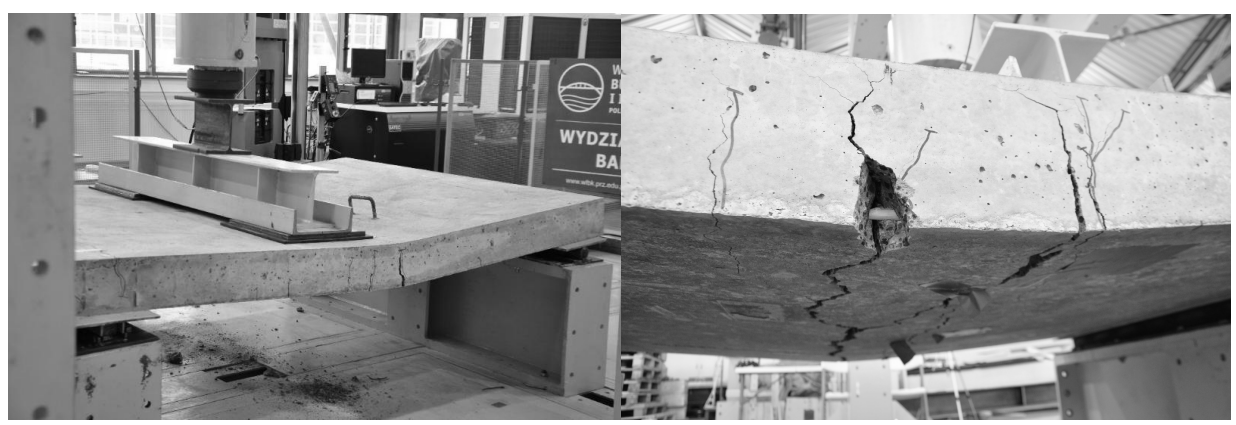

Rys. 18. Postać zniszczenia płyty w wyniku zmęczenia

Fig. 18. Slab failure pattern after the fatigue test

Ocena przyczepności do betonu prętów kompozytowych GFRP została przeprowadzona na podstawie oględzin odcinka pręta kompozytowego na długości równej ok. 10d (rys. 19). Na tej podstawie stwierdzono, że pręty kompozytowe GFRP utraciły przyczepność do betonu. 


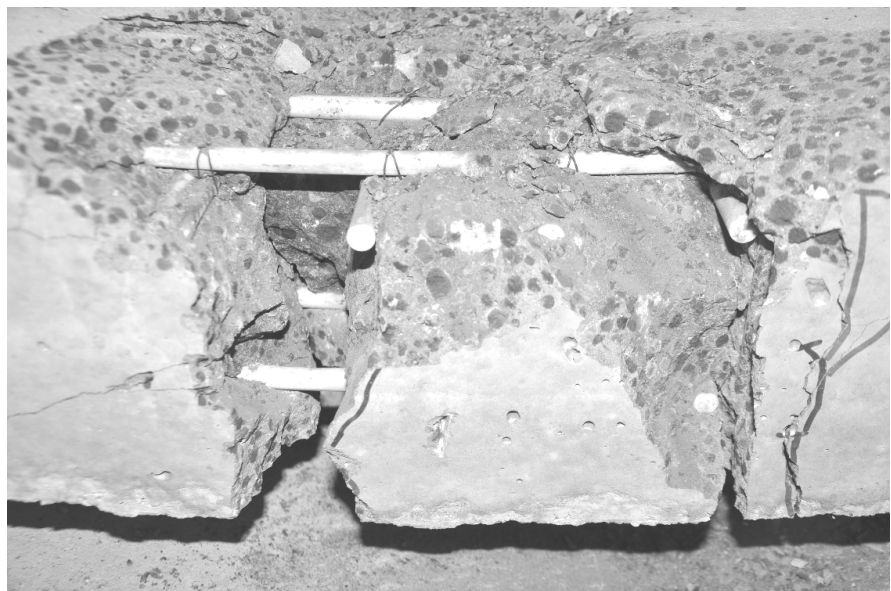

Rys. 19. Kontrola przyczepności prętów po lokalnym usunięciu betonu

Fig. 19. Rebars bond control after local concrete removing

\subsection{Analiza wyników badań zmęczeniowych}

Uzyskana w badaniach trwałość zmęczeniowa wynosiła 980,5 tys. cykli obciążenia odpowiadającego normowemu modelowi pojazdu FML1 [19].

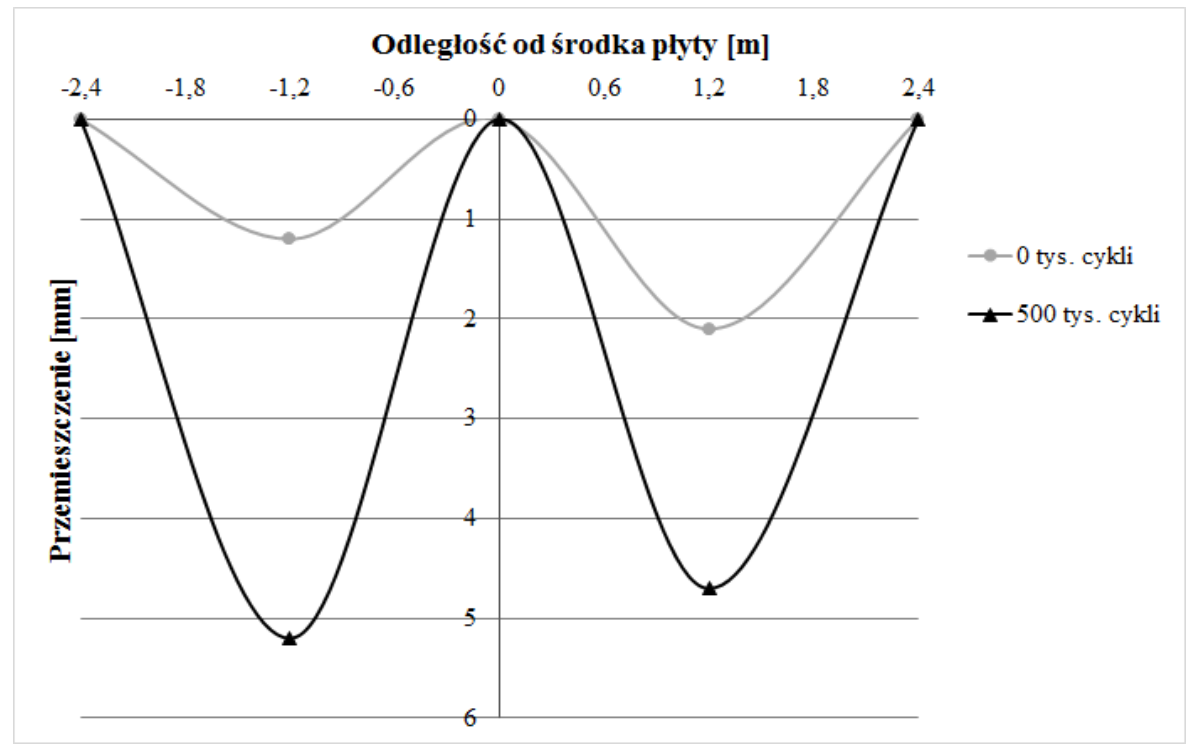

Rys. 20. Globalna utrata sztywności płyty pod wpływem 500 tys. cykli obciążenia zmęczeniowego FML1

Fig. 20. The global loss of slab stiffness after 500,000 cycles of FML1 fatigue loading 
Utrata nośności zmęczeniowej nastąpiła na skutek gwałtownej utraty sztywności płyty, spowodowanej utrata przyczepności prętów GFRP do betonu. Pręty nie uległy jednak zniszczeniu. Uzyskanej wartości nie można porównać do wymagań normowych, gdyż wytyczne ACI [2] nie zawierają żadnych informacji na temat analizy zmęczeniowej płyt pomostu zbrojonych prętami kompozytowymi GFRP. Analizę wyników badań zmęczeniowych przeprowadzono również $\mathrm{W}$ oparciu o utratę sztywności modelu M3 na poziomie obciążenia $\mathrm{P}_{\mathrm{k}}$ wywołującego $\mathrm{w}$ płycie pomostu wartość charakterystyczną momentu zginającego. Porównano sztywność modelu płyty pomostu przed rozpoczęciem obciążenia zmęczeniowego oraz po 500 tys. cykli obciążeniem zmęczeniowym (rys. 20). Stwierdzono ok. 4,3-krotny spadek sztywności modelu M3 w przęśle P1-P2 oraz 2,8-krotny w przęśle P2-P3.

\section{Podsumowanie}

W pracy opisano badania mające na celu określenie zachowania się płyt pomostu z betonu lekkiego zbrojonego prętami kompozytowymi GFRP pod obciążeniem statycznym i zmęczeniowym. Badania przeprowadzono na trzech modelach badawczych, odpowiadających geometrycznie płytom stosowanym w rzeczywistych obiektach mostowych. Przeprowadzone badania wykazały, że prototypowe panele pomostowe charakteryzują się dużą nośnością, trwałością zmęczeniową oraz zachowują się sprężyście aż do zniszczenia, które ma charakter pseudo-sprężysty.

Analiza wyników badań statycznych wykazała wystarczającą nośność i sztywność badanych płyt pomostu do zastosowań w obiektach mostowych. Ponadto analiza porównawcza nośności uzyskanych doświadczalnie z wartościami obliczonymi według wytycznych ACI [2] wykazała bardzo dobrą zgodność w zakresie nośności na zginanie oraz nieadekwatność tej normy w zakresie szacowania nośności na ścinanie. Głównym powodem wydaje się fakt, że wytyczne [2] nie uwzględniają $\mathrm{w}$ procedurze obliczeniowej zastosowania betonu lekkiego.

Badania zmęczeniowe nie potwierdziły nieograniczonej $(2 \mathrm{mln}$ cykli) nośności zmęczeniowej płyty pomostu. Na podstawie badań zmęczeniowych wyznaczono niszczącą liczbę cykli, która wyniosła 980,5 tys. przy wartości obciążeniu 210 kN na oś wg modelu FLM1 [19]. Utrata nośności zmęczeniowej nastąpiła na skutek gwałtownej utraty sztywności płyty, spowodowanej utrata przyczepności prętów GFRP do betonu. W rzeczywistości jednak obciążenie eksploatacyjne płyty pomostu (np. przy założeniu nośności mostu $40 \mathrm{t}$ według normy [16]) będzie znacząco mniejsze, dlatego wynik badań zmęczeniowych przyjęto za zadowalający. Wytyczne ACI [2] nie przewidują sprawdzania nośności zmęczeniowej betonowych płyt pomostu zbrojonych prętami kompozytowymi FRP. 
Na podstawie badań statycznych i zmęczeniowych stwierdzono, że modele płyt miały wystarczającą sztywność oraz nośność doraźną i zmęczeniową. Modele płyt spełniły stawiane przed nimi warunki zarówno w stanie granicznym nośności jak i użytkowalności. Uzyskane wyniki świadczą o poprawności przyjętego rozwiązania konstrukcyjnego, materiałowego oraz technologicznego. Problemem wymagającym dalszych badań jest zwiększenie przyczepności prętów GFRP do betonu. Można to uzyskać stosując użebrowane pręty kompozytowe, które są już dostępne na polskim rynku (np. www.comrebars.pl). Konieczne wydaje się przeprowadzenie badań płyt na ścinanie $w$ celu ustalenia procedur obliczeniowych pod kątem zastosowania betonu lekkiego. Zaleca się także przeprowadzenie badań zmęczeniowych dla większej liczby modeli płyt pomostu zbrojonych prętami GFRP w celu wyznaczenia pełnej krzywej Wöhlera, niezbędnej do projektowania takich pomostów.

Badania zostały zrealizowane $\mathrm{w}$ ramach Przedsięwzięcia Pilotażowego „Wsparcie badań naukowych i prac rozwojowych w skali demonstracyjnej DEMONSTRATOR+”, projekt pn.: „COM - BRIDGE - Innowacyjny most drogowy $\mathrm{z}$ kompozytów FRP” (umowa $\mathrm{nr}$ UOD-DEM-1-041-/001), współfinansowanego przez Narodowe Centrum Badań i Rozwoju.

\section{Literatura}

[1] Abdul Salam B.: Behaviour of shear critical FRP reinforced concrete one-way slabs, Doctoral Thesis, Universite de Sherbrooke, Quebec, Canada, 2014.

[2] ACI 440.1R-06. Guide for Design and Construction of Structure Concrete Reinforced with FRP Bars.

[3] Alsharif F.: Structural behavior of lightweight concrete bridge deck slabs reinforced with basalt FRP bars, Master of Science Thesis, University of Illinois at Chicago, 2014.

[4] Benmokrane B., El-Salakawy E., El.,-Ragaby A., Lacky T.: Design and Testing of Concrete Bridge Decks Reinforced with Glass FRP Bars, Journal of Bridge Engineering, vol. 11, no. 2, 2006, pp. 217-229.

[5] Benmokrane B., El-Salakawy E., El-Ragaby A., El-Gamal S.: Performance evaluation of innovative concrete bridge deck slabs reinforced with fibre-reinforcedpolymer bars, Canadian Journal of Civil Engineering, vol. 34, no 3, 2007, pp. 298310.

[6] El-Ragaby A., El-Salakawy E., Benmokrane B.: Fatigue analysis of concrete bridge deck slabs reinforced with E-glass/vinyl ester FRP reinforcing bars, Composites Part B: Engineering, vol.38, no.5-6, 2007, pp. 703-711.

[7] El-Ragaby, A., El-Salakawy, E.F., Benmokrane, B.: Experimental Investigation on the Fatigue Behaviour of GFRP Reinforced Concrete Bridge Deck Slabs, Proceedings of the 1st International Structural Specialty Conference, CSCE Annual Conference, Calgary, Alberta, Canada, May 23-26, 2006 Paper ST-126, CD-Rom: pp. 1-10. 
[8] El-Salakawy E., Benmokrane B., El-Ragaby A., Nadeau D.: Field investigation on the first bridge deck slab reinforced with glass FRP bars constructed in Canada, ASCE Journal of Composites in Construction, vol.9, no.6, 2005, pp.470-479.

[9] Hassan T., Rizkalla S., Abdelrahman A., Tadros G.: Design recommendations for bridge deck slabs reinforced by fiber reinforcement polymers. Proceedings of 4th International Symposium on Fiber Reinforced Polymers Reinforcement for Concrete Structures, FRPRC-4 ACI-SP-188, Baltimore, 1999, pp. 313-324.

[10] Holden K., Pantelides C., Reaveley L.: Bridge constructed with GFRP-reinforced precast concrete deck panels: case study, Journal of Bridge Engineering, vol.19, no. $5,2014$.

[11] Japan Concrete Institute.: Non-metallic (FRP) reinforcement for concrete structures, Proceedings of 3rd International Symposium (FRP RCS-3), Sapporo, Japan, vol. 1, 1997.

[12] Liu R., Pantelides C.P.: Shear strength of GFRP reinforced precast lightweight concrete panels, Construction and Building Materials, vol. 48, no.11, 2013, pp. 51-58.

[13] Mahroug M. E. M., Ashour A. F., Lam D.: Experimental response and code modelling of continuous concrete slabs reinforced with BFRP bars, Composite Structures, vol.107, 2014, pp.664-674.

[14] Nanni A., Faza S.: Designing and constructing with FRP bars: An emerging technology, ACI Concrete International, vol. 24, no. 11, 2002, pp. 53-58.

[15] Pantelides C. P., Liu R., Reaveley L. D.: Lightweight concrete precast bridge deck panels reinforced with glass fiber-reinforced polymer bars, ACI Structural Journal, vol.109, no.6, 2012, pp. 879-888.

[16] PN-85/S-10030. Obiekty mostowe. Obciążenia. Warszawa, 1985.

[17] PN-EN 1254 - Część 1:2001. Badania betonu w konstrukcjach - Odwierty rdzeniowe. Wycinanie, ocena i badania wytrzymałości na ściskanie.

[18] PN-EN 13791:2008. Ocena wytrzymałości betonu na ściskanie w konstrukcjach i prefabrykowanych wyrobach betonowych.

[19] PN-EN 1991-2:2005. Oddziaływania na konstrukcję .Obciążenia ruchome mostów.

[20] PN-EN 1992-1-1:2008. Eurokod 2. Projektowanie konstrukcji z betonu. Część 1-1: Reguły ogólne i reguły dla budynków

[21] Rizklla S., Tadros G.: First smart bridge in Canada. ACI Concrete International, vol. 16, no. 6, 1998, pp. 42-44.

[22] Saadatmanesh H, Ehsni M. R.: International conference on composites of infrastructure. Proceedings of ICCI, Tucson, Arizona, 1996.

[23] Wiater A., Rajchel M., Siwowski T.: Analiza obliczeniowa płyt pomostowych $\mathrm{z}$ betonu lekkiego zbrojonego prętami GFRP w świetle badań doświadczalnych, Inżynieria i Budownictwo, 2016 (w druku).

[24] Yost J.R., Uzman Z., Gross S. G., Iglesias J.: Shear strength of continuous GFRP reinforced concrete beams subjected to uniform load, Proceedings of the 7th International Conference on FRP Composites in Civil Engineering (CICE). International Institute for FRP in Construction, 2014. 
[25] Yost, J. R., Dinehart D. W., Gross S. P., Reilly P.: Fatigue Evaluation of a GFRP Reinforced Bridge Deck., Structure magazine, February 2014, pp 10-12.

\title{
RESEARCH ON DECK SLABS MADE OF LIGHTWEIGHT CONCRETE AND REINFORCED WITH GFRP BARS
}

\begin{abstract}
S u m m a r y
The bridge concrete deck slabs have got the least durability among bridge structural elements. One of the way of the durability enhancement is the use of non-metallic rebars with excellent corrosion resistance, high strength and low self-weight. The research recently conducted in Canada, USA and Japan both in laboratory and under traffic have revealed the concrete bridge deck slabs with GFRP rebars have had good structural behavior and much higher durability. The main goal of the paper is the presentation of research works on static and fatigue behavior of three concrete slab models with GFRP rebars. The carrying capacity of the slabs as well as fatigue durability have been checked during experimental tests. To reduce the self-weight of the slabs the structural lightweight concrete has been used. Experimental results have been compared to code-checking calculations, showing main discrepancies. However the research clearly revealed, that bridge deck slabs made of LC concrete and GFRP rebars could be viable alternative for conventional concrete decks with steel rebars.
\end{abstract}

Keywords: bridge deck slab, GFRP rebars, lightweight concrete, structural testing, fatigue testing,

Przestano do redakcji:30.09.2015

Przyjęto do druku:10.01.2016

DOI: $10.7862 / \mathrm{rb} .2015 .211$ 